\title{
Bronze Age cereal processing in Southern Iberia: A material approach to the production and use of grinding equipment
}

\author{
Selina Delgado-Raack, Roberto Risch \\ Department of Prehistory, Universitat Autònoma de Barcelona, Edifici B, Facultat de Filosofia i Lletres, \\ E-08193 Bellaterra, Barcelona, Spain. \\ Email: Delgado-Raack: sdelgadoraack@hotmail.com; Risch: Robert.Risch@uab.cat
}

\begin{abstract}
:
During the last two decades important progress has been made regarding functional analysis on prehistoric grinding equipment, thanks to the application of new methods and techniques. Despite these efforts studies integrating archaeology, ethnography, geology and other disciplines related to the material sciences are still rare. The main focus of this paper is placed on the grinding equipment composed of two elements, grinding slab and rubber, acting in reciprocal abrasive contact. Starting from systematic petrological, morphometrical, and functional analysis, qualitative and quantitative data are considered to define the manufacturing and use of grinding tools participating specifically in the production of flour. Morphology and size of grinding slabs and rubbers, raw materials used for manufacturing them, their mechanical properties as well as the geographical management of rocks will be interrelated in this study. From a methodological perspective, socio-economic contexts where grain processing was the main food supplying strategy are of particular interest. In these contexts, access to mechanically optimal raw materials and technical equipment plays a crucial role in the social as well as biological reproduction of human communities. This was the case in the El Argar society of southeast Iberia, where barley became the main staple food and the basic good of large scale surplus production between 2200 and $1550 \mathrm{cal}$. BCE. We will use this archaeological context to highlight the complexity of macro-lithic tool analyses and in particular with regards to the study of grinding tools. The ultimate aim is to understand to what extent the technological parameters of this subsistence strategy were related to the development of class society.
\end{abstract}

Keywords: grinding tools; Iberian Early Bronze Age; functional analysis; mechanical properties; ground stone tools

\section{Introduction: The archaeological context of Argaric subsistence}

The Early Bronze Age El Argar society of southeastern Iberia (ca. 2200-1550 cal. BCE) is one of the most outstanding prehistoric entities of later European prehistory. Over its 650 years of existence this society developed into a complex hierarchical system organised mainly through a network of central hilltop settlements and smaller dependent sites scattered over c.

Published by the School of History, Classics and Archaeology, University of Edinburgh ISSN: 2055-0472. URL: http://journals.ed.ac.uk/lithicstudies/

This work is licensed under a Creative Commons Attribution 2.5 UK: Scotland License. 
$35.000 \mathrm{~km}^{2}$, during the final Argaric phase (Figure 1). Metallurgy played a strategic role not only in relation to the production of metal weapons, such as halberds and - after c. 1800 BCE - swords, but also with regards to the control over exchange networks and wealth distribution. Metallurgy was organised at an over-regional scale with different regions and settlements specialising in specific sectors of the production process. The social consequence of this organisation was restricted access to metal tools, weapons and ornaments, as expressed foremost in a markedly unequal distribution of copper and silver artefacts among the characteristic El Argar intramural burials (Lull et al. 2010; 2011).

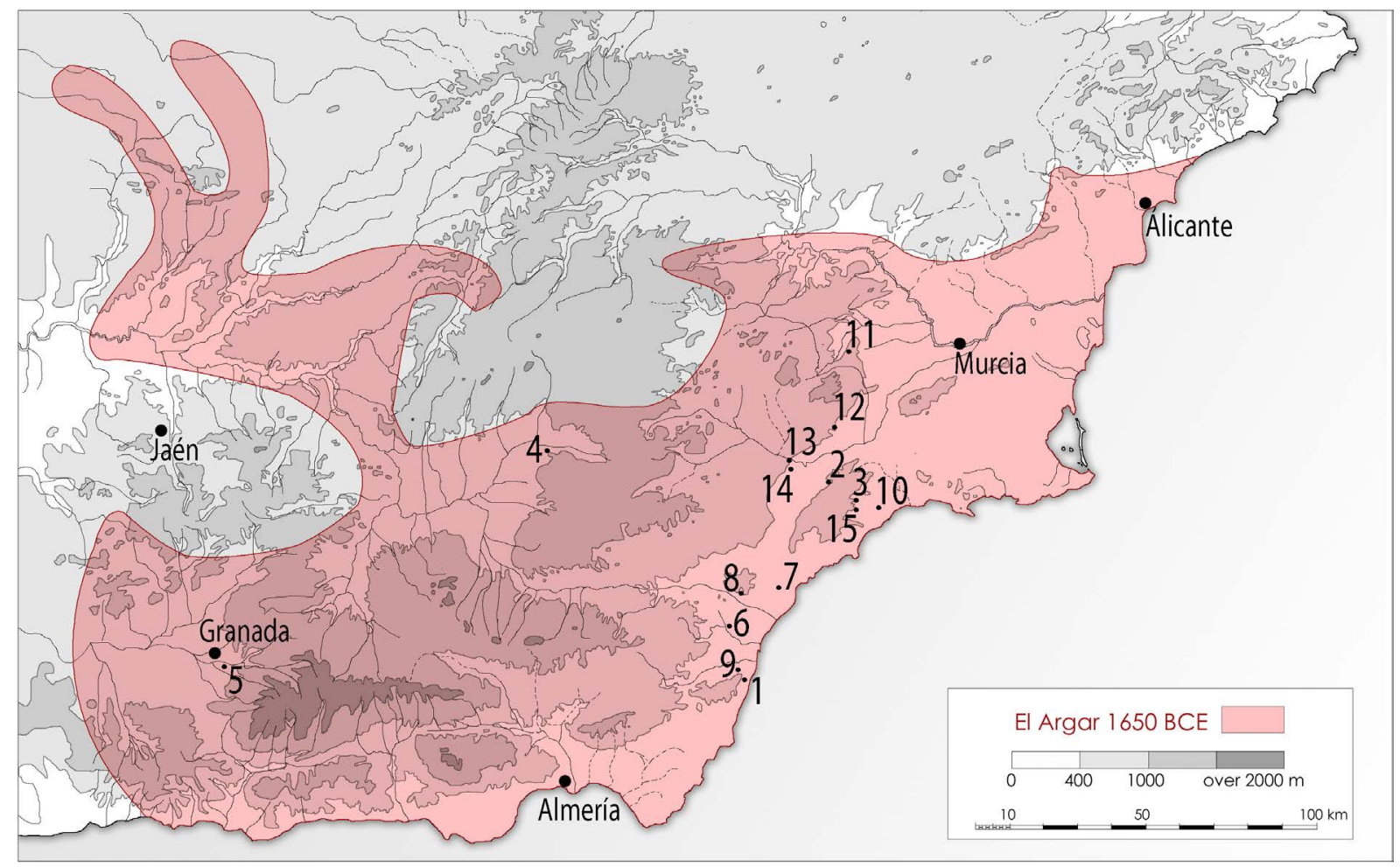

Figure 1. Maximal extension of El Argar around 1650 BCE and other sites mentioned in the text. 1. Barranco Ciudad; 2. Barranco de la Viuda; 3. Cabezo Negro; 4. Cerro de la Virgen; 5. Cerro de la Encina; 6. El Argar; 7. El Oficio; 8. Fuente Álamo; 9. Gatas; 10. Ifre; 11. La Almoloya; 12. La Bastida; 13. Lorca; 14. Los Cipreses; 15. Zapata. The lower scale bar is $100 \mathrm{~km}$ wide.

After the end of the Copper Age with its diversified subsistence strategies, the new economic regime was mainly based on the production and centralization of staple food (Risch 2002; Delgado-Raack 2008). Carpological studies suggest that El Argar increasingly specialised in barley cultivation at the expense of wheat, legumes and wild resources that were previously exploited (Stika 1988; 2001; Arnanz 1991; Ruiz et al. 1992; Clapham et al. 1994; 1999; Buxó 1997: tab. 6.4; Peña-Chocarro 2000).

A large proportion of the barley yield was centralised in c. 2-6 ha large hilltop settlements, where specialised storage and cereal processing devices have been found. Large pottery vessels or pithoi were used for storing grain and often stood in genuine warehouses, as it is the case in Gatas, Fuente Álamo, Cerro de la Encina or Ifre (Siret \& Siret 1890: Lám. 17; Molina 1983: 103; Risch 1995; Schuhmacher 2003). Moreover, in some sites like Fuente Álamo, specialized granaries seem to have existed (Schubart et al. 2001). Metric and usewear analysis of a specific type of standardised bowls suggest that grain was redistributed in normalized volumes for processing and consumption (Castro et al. 1999; Delgado-Raack \& Risch 2015: fig. 6). 
In the hilltop settlements of Gatas and Fuente Álamo different grinding workshops were found, in which a large number of grinding tools were used or even stored (Risch 1995; 2002; Delgado-Raack 2008). Flour production, estimated based on the number of simultaneously used grinding tools, exceeded the local subsistence needs and could have supplied a population of c. 1000-2000 persons, apparently living in the territory controlled by each hilltop settlement. These economic and political centres seem to have functioned as sort of cereal banks and mills in a centralized and redistributive system. Moreover, they are usually located several kilometres away from the fertile plains, where the potential lands for agriculture and husbandry, especially in the case of cattle holding, are found.

Despite extreme erosion and sedimentary processes, which characterize the geomorphology of southeastern Iberia, archaeological surveys and a limited number of excavations have started to provide some insight into these isolated dwellings scattered along the valley bottoms. These settlements show proportionally more harvesting tools such as sickle blades and significantly less grinding tools than the central sites (Ayala 1991; Martínez Rodríguez et al. 1999: 156-182; Martínez Sánchez 2000; Martínez Rodríguez et al. 2003). According to our socio-economic model of El Argar, the unfortified lowland farming villages handed over to the hill-top settlements an important part of their barley production through some form of tribute system. At the same time, these small villages, in which no metallurgical production seems to have taken place, would have been able to access certain manufactured products such as textiles and certain metal tools through their dependent relationships with the central sites.

The intensification of barley production was identified in the charcoal and pollen records, which suggest an important environmental degradation and deforestation process during the final stages of the Argaric development (Castro et al. 1998: 81; 1999: 185-187; Carrión et al. 2001; 2003; 2007). An extensive cereal monoculture, together with an increasing demand for fuel for metal and pottery production, triggered the first process of aridification and salinization detected in the Tertiary basins of southeast Iberia. In a context of increasing aridity, the preference for barley production as the main staple food over wheat and other more demanding crops could have appeared to be a good solution. Nevertheless, the high fibre content diminishes the nutritional value of barley. Indications of a poor diet are seen in the osteological record during the final stages of the Argaric period. Evidence of malnutrition and anemia appeared at that time as well as the highest infant mortality rates (Buikstra et al. 1990; Kunter 1990; Castro et al. 1995; Buikstra et al. 1999; Robledo \& Trancho 2003).

In this context of agricultural expansion and intensive barley processing and consumption, grinding technology must have become a strategic technology for the success of the whole economic system. The aim of this paper is to evaluate the technical parameters, which determine the functioning of this grinding equipment. In the light of the technical and material conditions, the organization of the forces of production will be considered as well as the relations established around cereal grinding.

\section{Materials and methods}

Prehistoric grinding equipment is often composed of a boat-shaped grinding slab with an active surface worn by friction. This static tool was used together with a rubber as the mobile part of the grinding equipment. Both elements are used to transform a third material. Ethnographic and archaeological evidence indicates that a large variety of tasks, ranging from crushing of minerals and processing of animal hides to grinding of a variety of plants, are carried out by means of different abrasive artefacts. Depending on the qualitative and quantitative aspects of these three parts, which compose the tribosystem, grinding will be performed more or less efficiently. Several parameters can be recorded. The physical 
properties of the tools are related to the state of a body (e.g., density, morphology, dimensions and mineral contents). The mechanical properties of the bodies address the behaviour of materials under certain conditions (e.g., temperature, load, friction, etc.). Apart from the physical and mechanical parameters, there are other parameters that influence the behavior of grinding equipment, such as kinetics, position and weight of the worker or even the time and periodicity dedicated to the work process. Most of them are not directly measurable in archaeology, so that it is very difficult to use them here as references for the evaluation of efficiency of grinding equipment.

The main criteria needed to identify prehistoric cereal grinding equipment are the technical correspondence between the grinding slab and the rubber or handstone. In terms of shape, size and geology, the abrasive surfaces of both artefacts must be designed in a way to warrant an easy pulverising of the cereal grain. While the larger grinding slabs are usually easy to define, the identification of the corresponding stone rubbers among the variety of small size abrasive tools usually found in the archaeological sites is much more difficult. Much less attention is devoted to the artefacts used for the maintenance of the grinding slabs and rubbers. Pecking and polishing stones are usually required to restore the roughness of the grinding surface and thus should be considered as part of the grinding equipment too (Hayden 1987; Risch 2002: 129-132; Delgado-Raack \& Risch 2009). Although pecking generates almost rough surfaces, polishing is needed to smooth it before grinding starts. Through both types of tools a balance is achieved between too much and too little roughness. Indeed, in southeastern Spain we find pebbles with both kinds of use-wear traces on their active surfaces next to the grinding stones (Delgado-Raack 2008: 371-380).

The first challenge of any macro-lithic study concerned with the economic and social context of cereal processing relies on the identification of the grinding equipment implied in these tasks. We will use El Argar as a case study in order to show that the usual typological tool classifications can be problematic and misleading. At the present moment the macrolithic database of south-east Iberia comprises several thousand artefacts. Given the focus of this study, only grinding tools coming from well-dated El Argar contexts are included (Figure 1).

\section{Results: Technological features of El Argar grinding equipment}

Shape, size and use-wear traces are used in this case as the main criteria in order to define the El Argar grinding slabs and their corresponding rubbers. In order to address the technological and economic implications of these tools we then turn to the geology and the mechanical properties of the raw materials used in different Argaric settlements. These mechanical differences will reveal the socio-economic differences that exist inside the settlements, as well as between them.

\subsection{Morphology}

The first technical condition of the grinding process is a perfect adjustment between the grinding slab and the rubber that allows the crushing and pulverising of the grain. Consequently, the active sides of both tools must present morphologically adapted shapes. Hürlimann (1965: 78-80) was the first to point out the morphological interdependence between both grinding surfaces. Later, Zimmermann (1988: 725) presented a model that explained the shape of the working surfaces as a mechanical consequence of the absolute metrical relation existing between both artefacts. However, ethnographic, experimental and archaeological information suggests that the correspondence between the different shapes can be more variable. The height of the convexity or the depth of the concavity of the grinding stones, as well as the absolute metrical relation existing between both artefacts, rather than 
just their morphological match, are relevant factors in the material wear and shaping of the grinding surfaces. The way rubbers are handled (e.g., in a circular or a reciprocal movement) is another factor that must be taken into account (Adams 1999). Based on the still limited amount of available experimental and ethnographic observations, a general morphometrical model of correspondences has been proposed (Risch 2008; Delgado \& Risch 2009). In the case of El Argar this model can be narrowed down to the combination between the transverse profile of the grinding slab and the longitudinal one of the rubber (Table 1).

Table 1. Morphology of the transverse profile of the active surfaces of grinding slabs and potential stone rubbers from well dated El Argar contexts of Fuente Álamo, Gatas, Lorca, Barranco de la Viuda, Los Cipreses and Cerro de la Virgen.

\begin{tabular}{llllll}
\hline $\begin{array}{l}\text { Morphometrical coupling of } \\
\text { grinding slabs and rubbers }\end{array}$ & \multicolumn{3}{c}{ Grinding slabs } & \multicolumn{3}{c}{ Rubbers } \\
& 203 & 65.07 & 20 & 46.51 \\
\hline
\end{tabular}

Most of the El Argar grinding slabs have a concave longitudinal section combined with a convex transverse section (Table 1). Such shapes and sections were practically unknown during the Copper Age and represent a technical novelty of the Early Bronze Age of southeast Iberia. According to the morphometrical model, Argaric stone rubbers should have a concave longitudinal and a convex or straight transversal morphology in order to make the grinding process possible. This principle raises a problem in Argaric grinding systems, however, since there is a general lack of stone rubbers that could fit with these grinding slabs. Less than one third of the macro-lithic artefacts described as rubbers on purely typological grounds conform to the active surface of El Argar grinding slabs. Moreover, quantities of slabs and stone rubbers are clearly disproportionate. According to the principles governing the material behaviour of abrasive surfaces, the latter should outnumber grinding slabs in the archaeological assemblage.

The wear indices obtained through experimental analysis using sandstone artefacts were five times higher for the mobile element than for the stable component (Wright 1993). Information gained among American as well as African societies suggests that the mean lifespan of stone rubbers is approximately half that of the grinding slabs. This would explain why the proportion of 2:1 is frequently encountered in archaeological cases where grinding slabs with flat or concave transverse profiles are predominant. According to the available ethnographic sources, the number of handstones per grinding slab is 2:1 for Highland Maya (Mesoamerica, Horsfall 1987); 1:1 for Bende (Ghana, unpublished); >6:1 for Sáhara (Holter \& Schön 1988); 2.5:1 for Kanuri (Nigeria; Gronenborn 1994); 1.9:1 for Hopi Indian 
settlements (Bartlett 1933). This pattern is ruled by the principle that the wear of two abrasive surfaces, which are in constant contact, is inversely proportional to their size.

\subsection{Dimensions}

The difficulty of finding adequate stone rubbers for the Argaric grinding slabs becomes even more pronounced if we take into account the dimensions of the artefacts. According to Zimmermann (1988), grinding slabs with a convex transverse profile result out of the use of long stone rubbers, as shown in Table 1. Our own ethnolographic observations in northern Ghana have confirmed this prediction. Local women attributed the slightly convex transverse shape of their tools to the fact that the body weight is not distributed evenly between the left and the right hands during the whole grinding process, as we had also predicted based on experimental tests (Menasanch et al. 2002). However, there also exist archaeological and ethnographic examples with a flat transverse section, which were used with stone rubbers that are c. 10-20 cm longer than the width of the grinding surface. We suspect that such shapes are the result of regular maintenance of the surfaces, rather than use-wear (Delgado-Raack \& Risch 2009).

If we consider the metric variables of the Argaric grinding equipment it becomes clear that the frequency distributions of active abrasive tools and passive slabs hardly overlap (Figure 2). It could be argued that some stone rubbers were recycled and used for other purposes, but this possibility is also likely in the case of broken grinding slabs, which are often found reused as building material. In sum, the El Argar macro-lithic record is defined by a marked scarcity of stone rubbers, which could be adjusted to the grinding slabs recovered in large quantities in the central hill-top settlements. This situation does not seem to be exclusive of El Argar, but also was observed in other Bronze Age contexts in the Aegean and the central Mediterranean (e.g., in Toumba Thessaloniki, Greece).

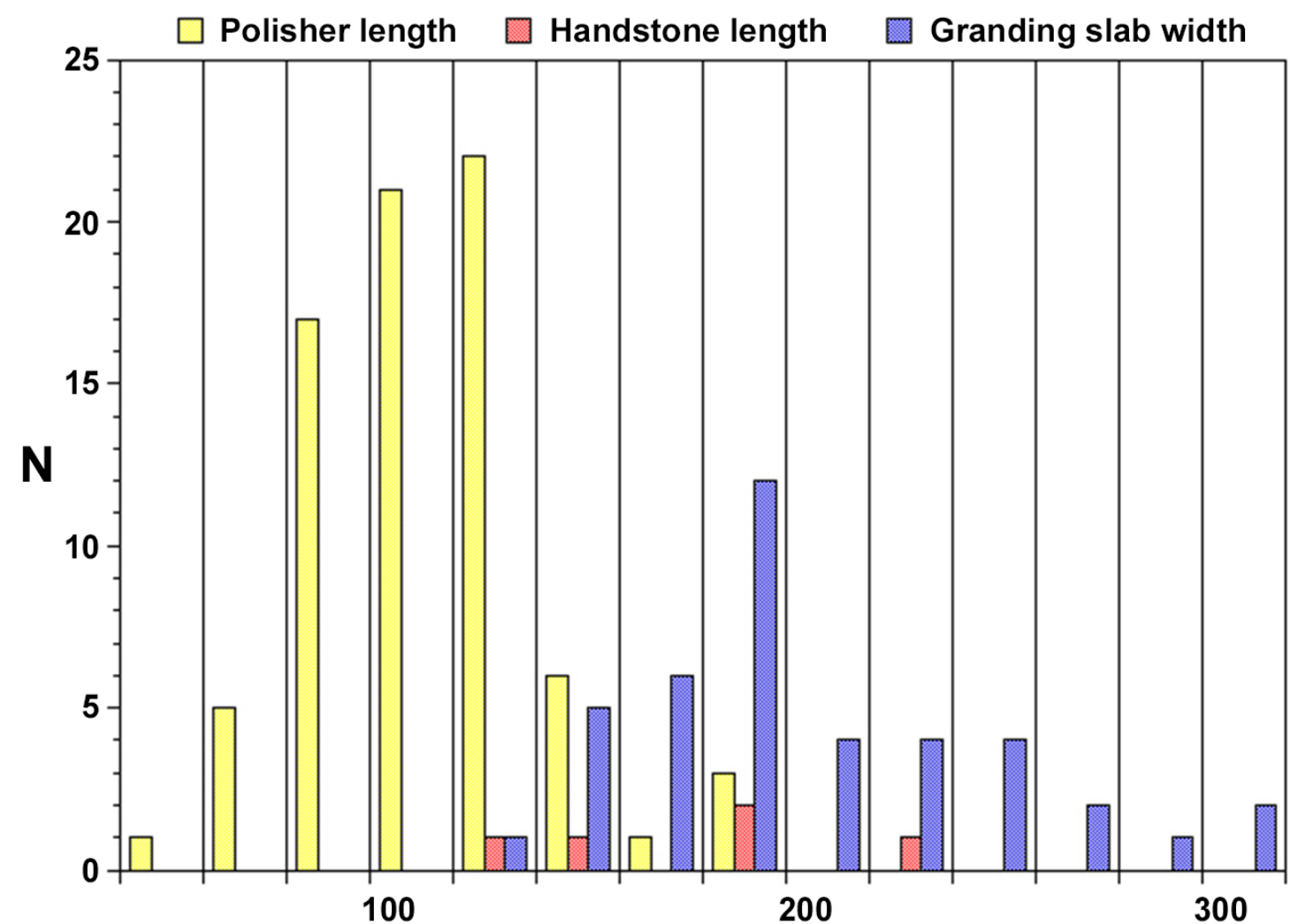

Figure 2. Comparison between the length of small abrasive tools and the width of the grinding slabs from the Bronze Age settlement of Gatas (Almería) (based on Castro et al. 1999: 110). 
In comparison to both the Copper Age as well as to the Late Bronze Age after $1550 \mathrm{cal}$. BCE, El Argar presents larger grinding surfaces as well as more elongated shapes, which at first sight would seem inappropriate for effective grinding purposes particularly in view of the slightly convex transverse profile. One would expect that grain seeds and fragments slide down during the grinding process on such narrow and slightly curved active surfaces. These observations suggest that a fully different grinding technology was introduced in Argaric times. Instead, rubbers of other raw materials must have been used. Only the combination of experimental tests and use wear analyses can provide a solution to this type of technological dilemma.

\subsection{Use}

The most frequent material implemented in the processing of agricultural products other than stone is wood. Apart from the wooden mortars and pestles for dehusking grain, the use of wooden rubbers is well known in western and central Africa and in Equatorial Guinea (Panyella \& Sabater 1959: 83; Pailler \& Garin, personal communication). The use of cork has been recorded in Morocco for dehusking grain (Peña-Chocarro 2000: 408; Peña-Chocarro \& Zapata 2003: 6; Peña-Chocarro et al. 2000). So far, two independent studies have been carried out to test the possibility that wooden rubbers were used in combination with the Argaric narrow grinding slabs with a convex transverse active surface (Risch 2002: 111-127; Delgado-Raack 2008: 292-347). In both cases experimental programs were designed in order to address the following technical and functional aspects:

a) The efficiency reached by the grinding systems using different lithotypes appearing in Argaric settlements (garnet bearing mica-schist and conglomerate). In this context, efficiency can be defined as the combination of labour return (amount of flour produced per unit of time) and grain yield (proportion between flour and bran obtained from a given volume of cereal),

b) The efficiency of the grinding systems using different types of stone and wooden rubbers,

c) The efficiency reached by the different grinding systems using barley and wheat,

d) The quality of the barley and wheat flour obtained under the different technological conditions,

e) The use-wear traces developed on the active surfaces of the grinding tools under different technological conditions.

The main result reached by these experiments was that the use of wooden rubbers represented a feasible choice. In fact, the use of wooden semi-cylindrical rubbers made of hard wood (Prunus sp.) developed a faster grinding process than stone rubbers under similar grinding conditions (Figure 3). The implementation of two materials with different textures and hardness (in this case, stone and wood) in reciprocal friction offers well known advantages, unlike the contact between two materials or rocks of the same type. Particularly interesting was to observe the effect of the wooden rubber on convex grinding stones. Contrary to what was expected, the grain, grain fragments, and flour did not slide towards the edges, but remained on or next to the central ridge of the surface, while the lighter bran slid down sideways towards the tool's margins. This effect was even more noticeable when processing barley.

Each time a new handful of grain was placed in the centre of the surface, the vibration of the grinding stone during the reciprocal movement produced the concentration of the heavier particles towards the higher ridge, and a simultaneous separation of the lighter bran (Risch 2002: 118, fig. 5.1). This material movement might have spared the sieving of flour, further improving the efficiency of cereal processing. In this context, the convex profile is not to be understood as a direct consequence of use, but as a technological feature maintained with a 
periodic retouching of the slightly curved grinding surface through a combination of pecking and smoothing. All experiments agree that the most efficient grinding equipment would be composed of a typical El Argar stone slab of garnet bearing mica-schist on which barley is processed with a wooden rubber.

1

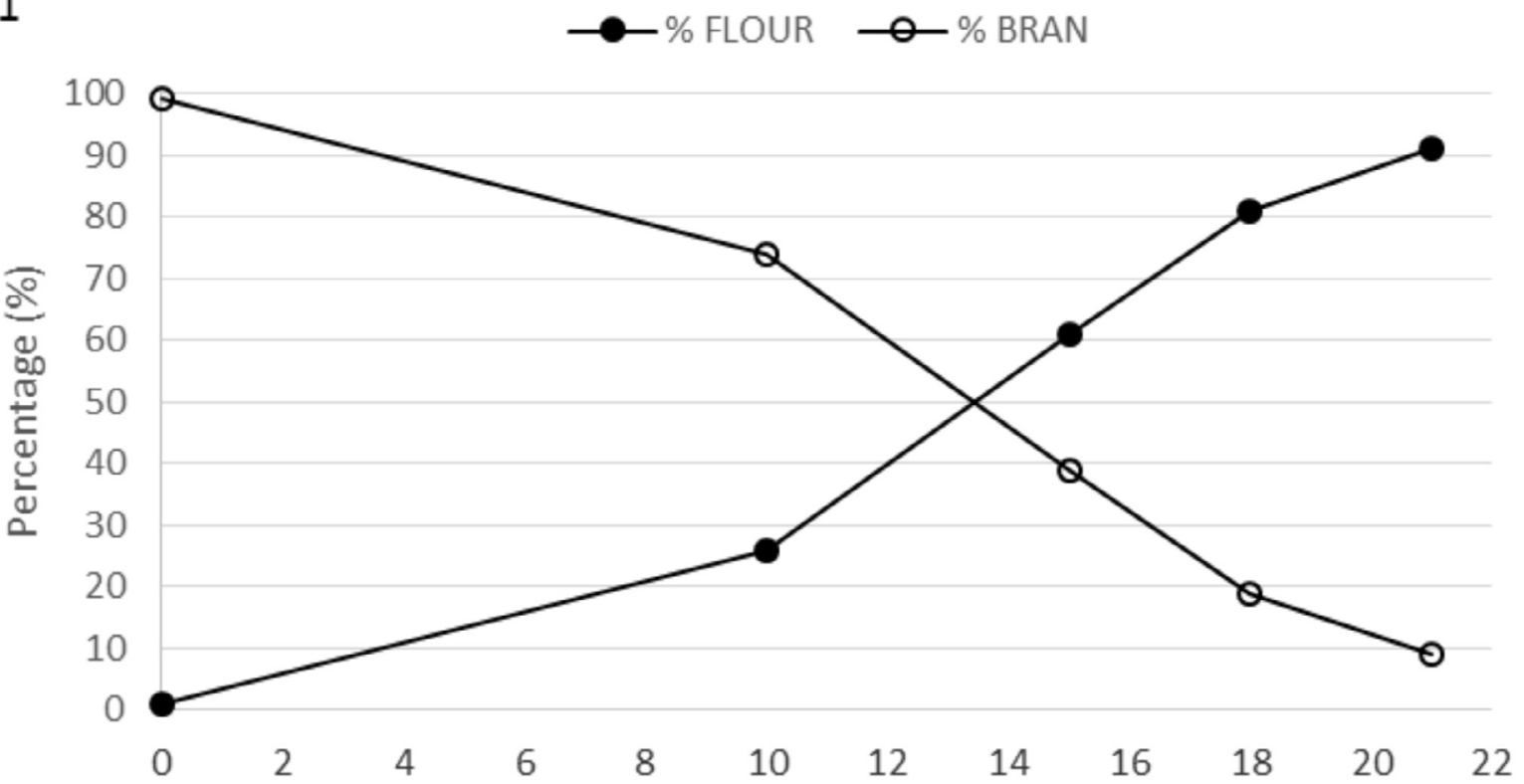

Minutes

2

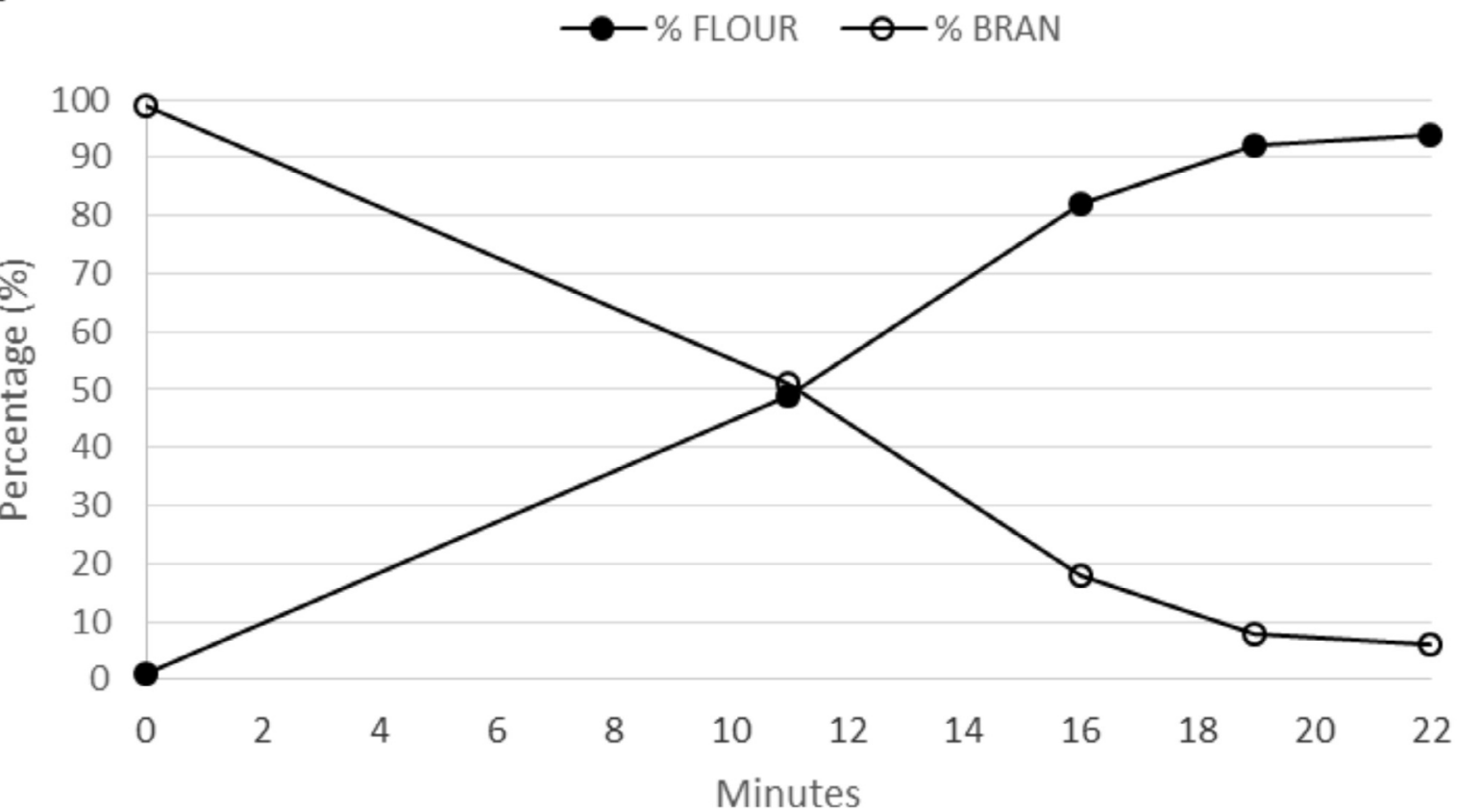

Figure 3. Experimental grain yield using (1) a handstone and (2) a wooden rubber. Values show the amount of flour against grain and bran (based on Risch 2002: 119, fig. 5.4).

The second conclusion resulting out of the experiments is related to the roughness of the working surface. Preparation of a grinding surface previous to work was crucial - its roughness must not be too low in order to avoid the rolling of grains across the surface, nor 
too pronounced because grains and grain fragments get trapped. Clearly the treatment of the surface morphology and roughness improves the grinding process.

Use-wear analyses combined with experimental work suggests that grinding surfaces were modified by a combination of activities, which may not be related solely to the use of tools but also to their manufacture and maintenance. While stone rubbers produce a use-wear pattern predominantly characterized by a levelled and smooth topography, surfaces worn out by wooden rubbers become much more sinuous and minerals show a clear edge rounding, indistinctly if we are dealing with conglomerate grinding slabs or with tools made of garnet bearing mica-schist (Figure 4). The friction against stone rubbers also generates other diagnostic use-wear patterns on the grinding slab, such as striations, fractures and grain extraction. The Argaric grinding surfaces present a complex pattern of traces that suggests the involvement of different raw materials and wear mechanisms resulting from the contact between hard and soft materials and from a combination of abrasion and percussion. The combination of experimental and archaeological information indicates that the tools used in the preparation and treatment of the convex grinding surfaces were hammerstones and polishers frequently made of quartzite, gabbro or similar rocks (Delgado-Raack 2008: 177179; 371-379).

A further feature, namely the distribution of high, levelled plateaus, allows the identification of the kinetic motion related to different artefact morphologies and the maintenance activities acting on the grinding surfaces. By means of charcoal replicas of the active surfaces of the grinding slabs, flat topographies were projected in opposition to anfractuosities, where abrasion is absent. This simple technique allows recognising the location of the most worn out zones of the surface. The frequency of black pixels in each part of the active surface gives a rough idea of the movements and pressure of the rubber during the grinding activity (Figure 5). The wear intensity on grinding slabs with a straight transverse section is most developed on the lateral flanks. This seems to result from using two-handed rubbers. The margins of the grinding surface would have been in direct contact with the rubber because of the absence of the grinding product in these areas. Concave grinding slabs exhibit a slightly more intensive wear in the central area of the grinding surface, where the pressure carried out by small one handed rubbers is highest. The most homogeneous distribution of the levelled topography is observed on the convex grinding slabs. As noted, this is the result of abrasive activities that were applied periodically in order to maintain the initial morphology and roughness of the surface. In sum, whereas the distribution of black pixels on straight and concave grinding surfaces is the result of use-wear, in the case of convex surfaces the more even levelling appears to be related to periodical maintenance activities. According to the use-wear patterns defined in the experimental program, the mesoscopic features (up to X10-100) visible on Argaric grinding slabs correspond to the production of flour with wooden rubbers (Figure 6). This type of combination of wear traces make up more than $70 \%$ of the surfaces.

The El Argar grinding slabs show not only the most curated, that is to say, regularly abraded and re-pecked active surfaces, but also the most worn tools in later prehistoric southeast Iberia. In terms of the relationship between thickness and length, the Argaric grinding equipment stands out as most intensively worn before it was abandoned or reused as building material, etc. (Delgado-Raack \& Risch 2015: fig. 12).

The introduction of wooden rubbers and slabs with a convex transverse profile at the beginning of the Argaric period must have supposed an important technological improvement in terms of efficiency of the grinding process. In comparison with other prehistoric periods, El Argar grinding technology presents the highest functional standardization as well as the highest wear in the grinding equipment. This specialisation correlates well with a more curated preparation and maintenance of the grinding surfaces. In sum, the predominance of 
specialised cereal grinding surfaces indicates a) the importance of cereal and, particularly, barley processing in the El Argar centralised economy and b) a generalized effort to improve the grinding process in terms of flour produced per unit of working time.

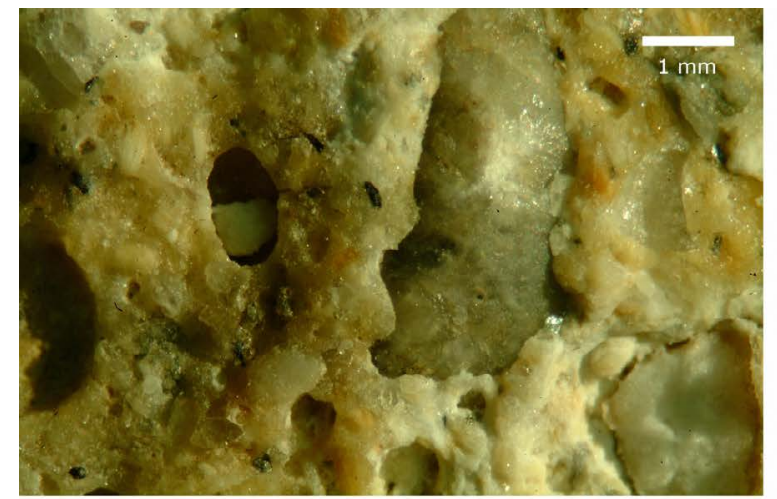

A

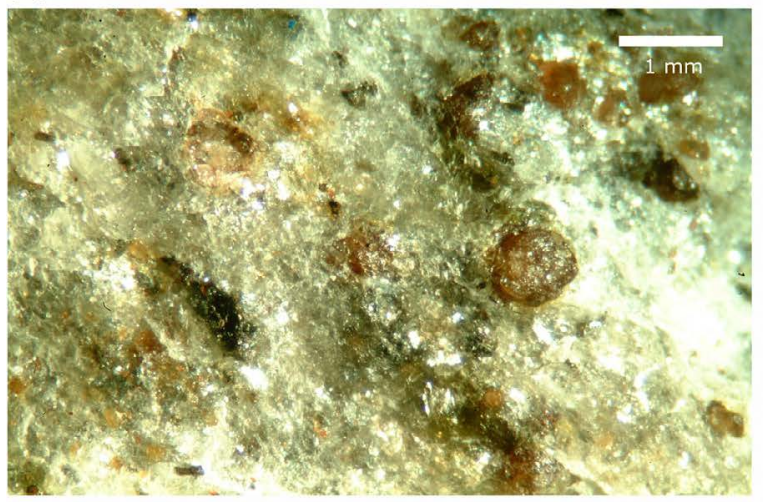

C

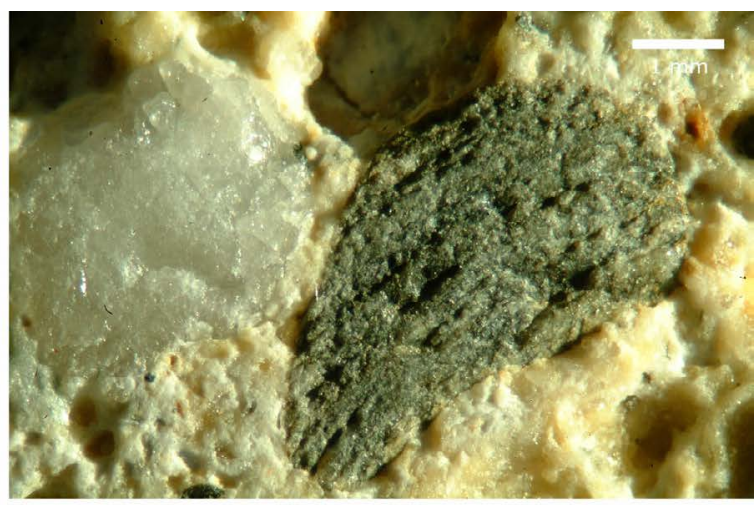

$\mathrm{B}$

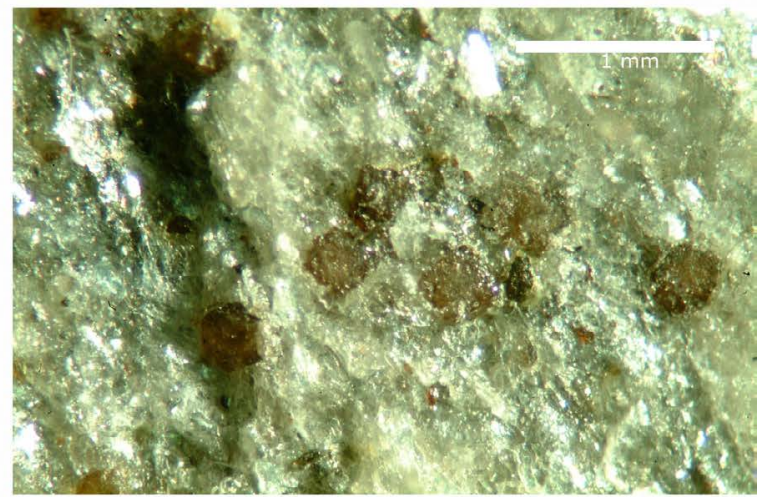

D

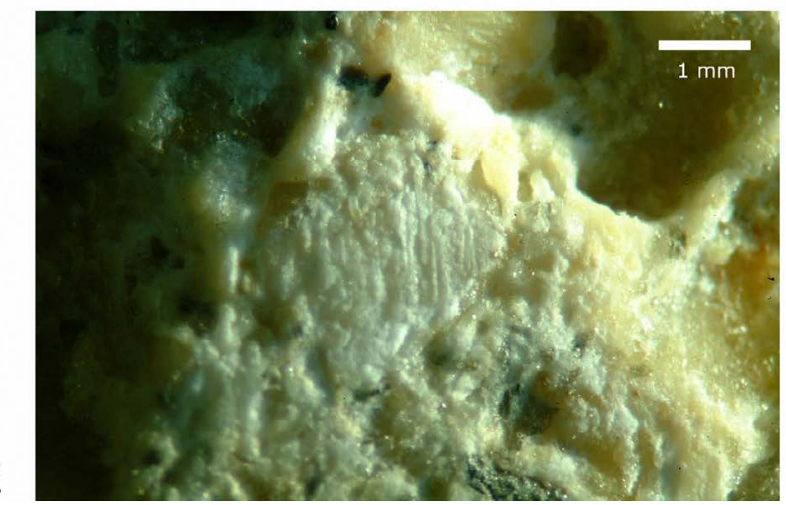

Figure 4. (a) Conglomerate grinding slab used for grinding barley during 30 minutes with a wooden rubber: a micro-fracture can be seen which affects the tip of a quartz grain; (b) Conglomerate grinding slab used for grinding barley during 30 minutes with a metapsammite rubber: levelled mineral grains dominate; (c) Garnet bearing mica-schist grinding slab used for grinding barley during 60 minutes with a wooden rubber: rounded garnet and sinuous topography; (d) Garnet bearing mica-schist grinding slab used for grinding barley during 60 minutes with a metapsammite rubber: garnets and micaceous matrix are worn to the same level, an unaltered garnet appears in low topography; (e) Conglomerate grinding slab used for grinding barley during 60 minutes with a metapsammite rubber: parallel micro-striations on mineral inclusion.

\subsection{Mechanical properties}

In a previous study we analysed the mechanical properties of several rock types used in the production of prehistoric grinding slabs (Delgado-Raack et al. 2009). The expectation was that the Argaric raw material supply had direct consequences to the social conditions of the 
grinding processes carried out in the different Argaric settlements. During the last years, new fieldwork and mechanical tests were carried out, strengthening the empirical basis with additional archaeological and experimental information.

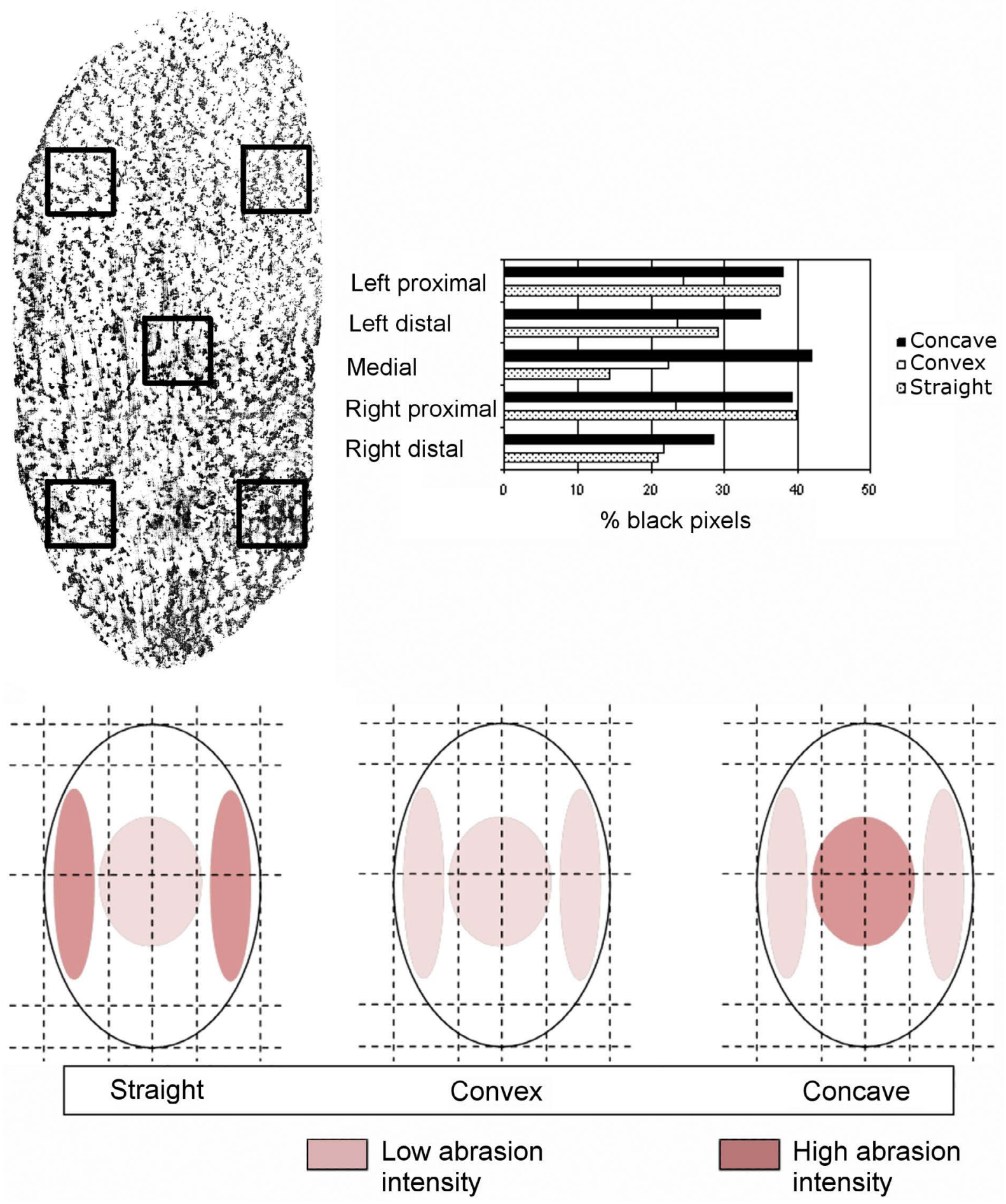

Figure 5. Average percentage of black pixels or levelled topography in the different parts of the active surface of grinding slabs from Guadalentín valley settlements (top); mapping of the abrasive intensity observed on grinding surfaces with different transverse profiles (bottom) (based on Delgado-Raack 2008: fig. 4.1.26). 

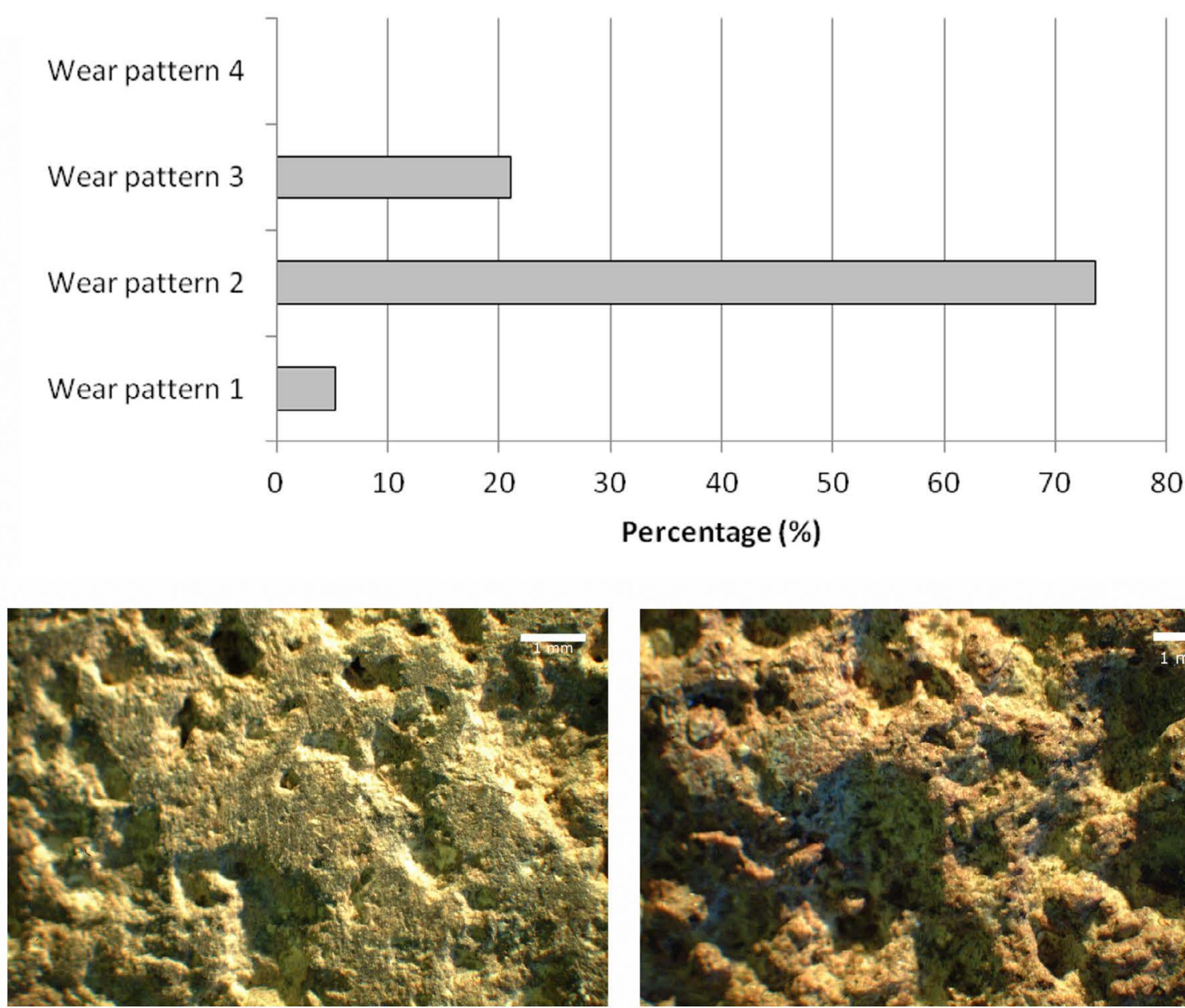

Wear pattern 1
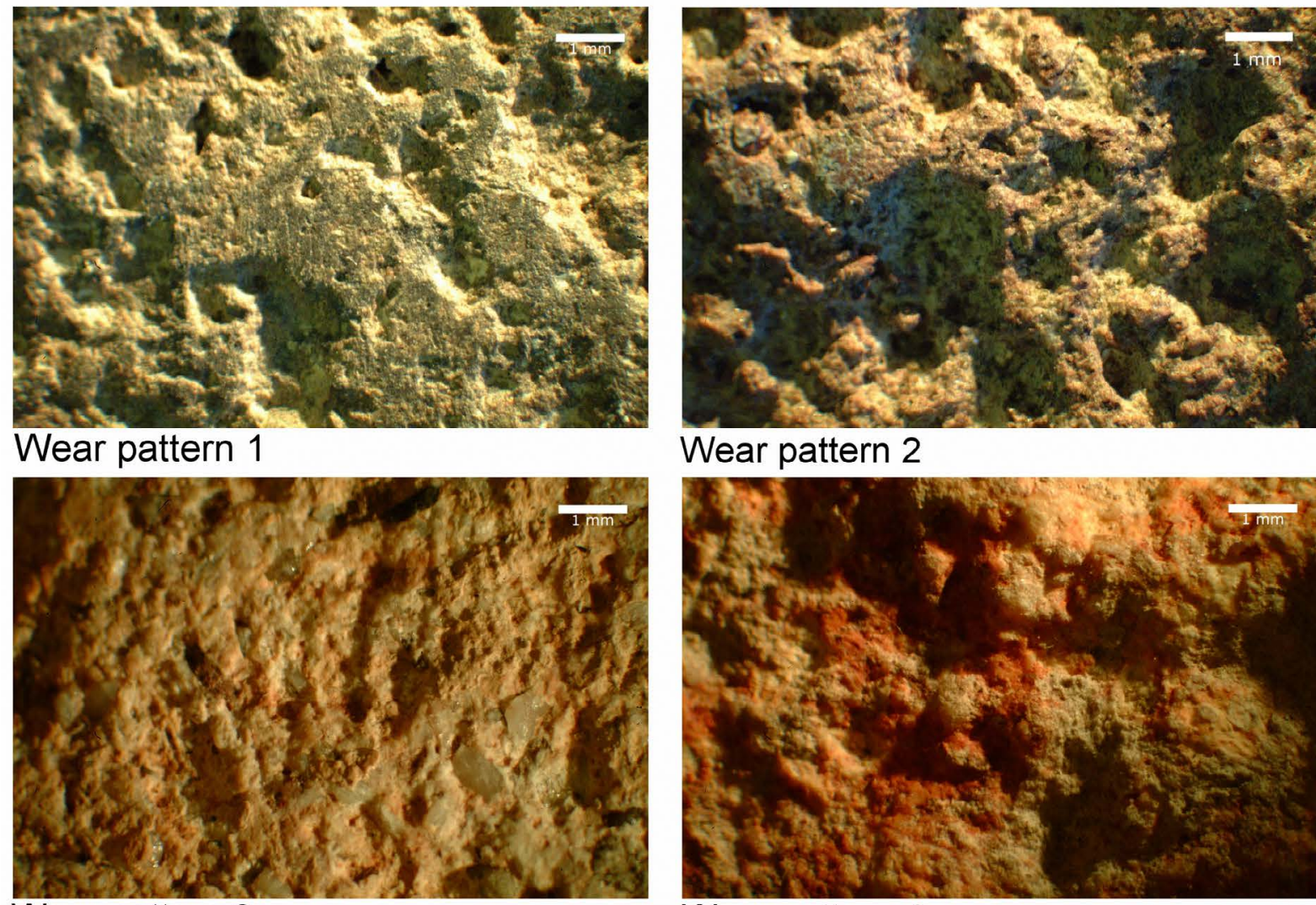

Wear pattern 2

Wear pattern 3

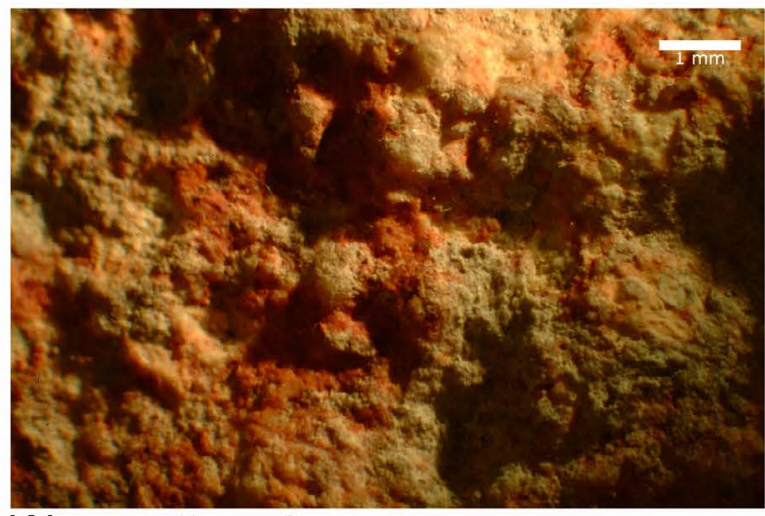

Wear pattern 4

Figure 6. Frequencies of wear patterns observed on grinding slabs from Argaric settlements of the Guadalentín valley (source for graphic, Delgado-Raack 2008: fig. 4.1.35; source for pictures Delgado-Raack 2008: 330-337). Wear pattern 1: grinding with stone rubber; 2: grinding with wooden rubber; 3: multifunctional use (friction, pounding, cutting); 4: mineral processing.

The lithological variability observed in the exploitation of rocks used in the manufacture of Argaric grinding slabs is high (Figure 7). This diversity is surprising in view of the standardisation of the other morphometric variables discussed above and seems to be a consequence of a specific raw material supplying system, in which the use of fluvial deposits close to the settlements was favoured and over-regional circulation of bulk materials was restricted (Risch 1995; Delgado-Raack 2008). Most of the rocks employed as macro-lithic 
tools were obtained in the economic territory controlled by each site, while exchange of rocks even between neighbouring settlements was limited. The resulting pattern of raw material distribution allows us to trace the possible political borders between economic territories with different lithic resources and dominated by individual central hill-top settlements (Risch 1995; 2002).

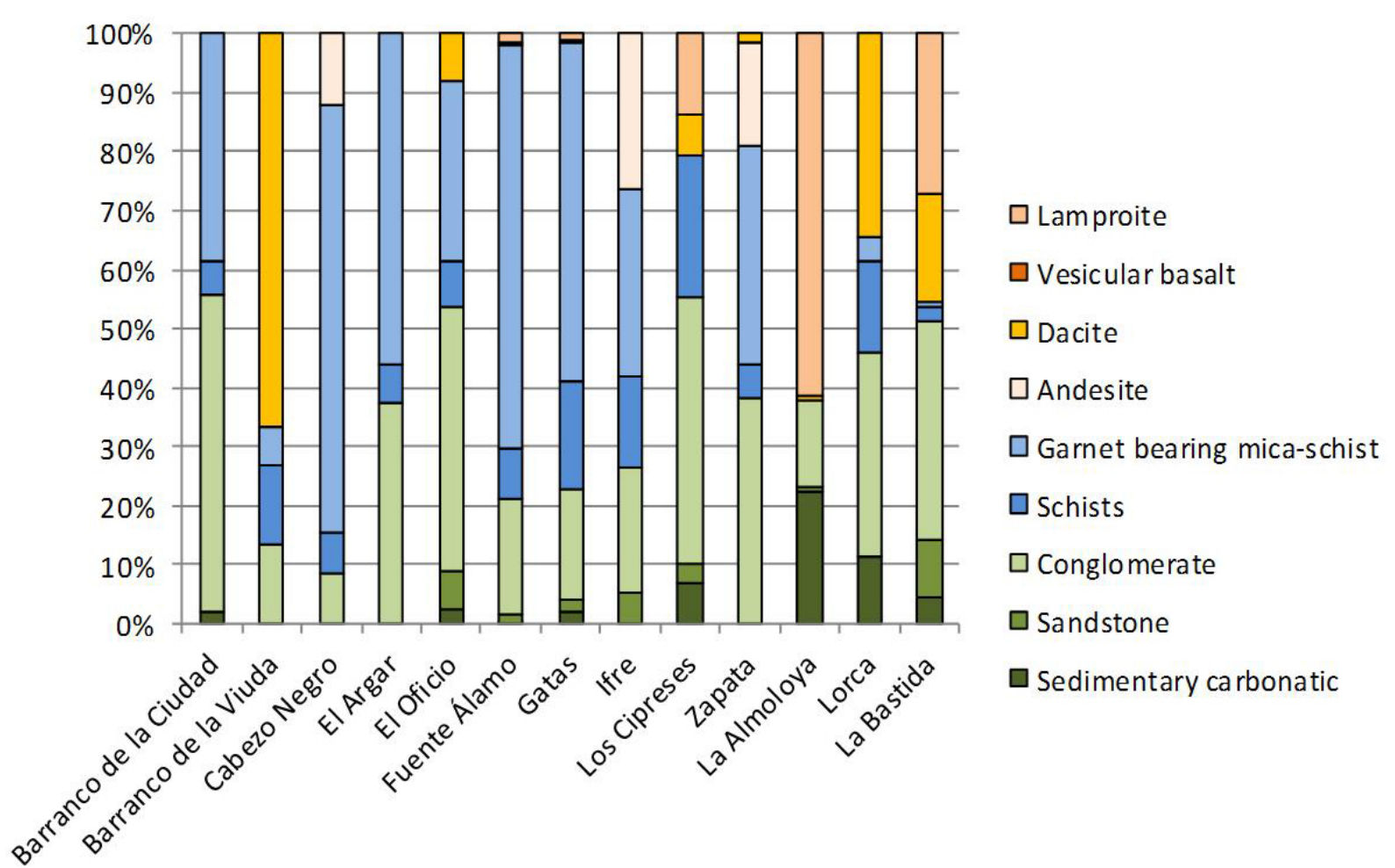

Figure 7. Frequency of lithologies used for the production of grinding slabs in different Argaric settlements.

In this case we wish to evaluate the mechanical properties of the technical equipment available in each analysed settlement. Tests were carried out with a Böhme industrial test machine. The technical requirements of the Böhme machine are rocks cut into metrically standardized samples, which are submitted to identical frictional stress. During the tests, samples support a $20 \mathrm{~kg}$ load while they rotate over a steel track in circular movements (27 rpm). Moreover an abrasive substance (ground corundum) is added in order to accelerate wear. The objective of these tests is not to replicate work processes as they happened in prehistory, but to characterize the mechanical behavior of rocks under controlled and systematic variables of mechanical stress. The test was used in order to measure the abrasive capacity of rocks. This concept derives from the relationship existing between two different behaviours that rocks develop when they are put under frictional wear: resistance against friction and development or maintenance of surface roughness. As both aspects are not always in causal relation (Delgado-Raack et al. 2009: fig. 1), it is necessary to evaluate them independently.

On one hand, resistance against friction affects the tools' dimensions, specifically its thickness, which diminishes through its use live. This parameter can be measured by means of the amount of material the tool loses during grinding (volume loss expressed in $\mathrm{cm}^{3}$ ). On the other hand, surface roughness is the capacity of a rock to renew its relief, which is the same as saying, to maintain the initial roughness conditions during frictional contexts. The quantification of roughness requires the use of profilometric techniques, in this case, tactile profilometry with a resolution of $0.001 \mathrm{~mm}$, which provides the $R a$ value (standard deviation 
to the arithmetic mean of surface roughness) of a profile. In this case, profiles were additionally corrected with the aid of a lineal detrending process (Anderson 1976).

These tests establish the mechanical differences of rocks in quantitative terms. In principle, rocks with a lower material loss should be preferred over more friable rocks, which will result in flour with higher contents in mineral particles. At the same time, grinding requires active surfaces of a specific roughness and, hence, abrasive capacity. Rocks with a low $R a$ value will need more frequent pecking or are less efficient. The differences between rocks used during El Argar are notorious in both parameters and have allowed to establish three groups of rocks with similar mechanical properties and, hence, similar technical thresholds. The establishment of the three types of mechanical behaviour is based on a relative scale (Risch 2008: P0/19tab). From this mechanical perspective, the technical conditions of cereal processing appear to have been very unequal between settlements but also inside of them. Household production was registered principally in small farmer villages of the plain, where we could say that the relative rock variability is higher. The majority of the analyzed Argaric grinding tools from the large, central settlements come from workshops, where intense grinding work was performed, as the high quantity of grinding slabs, grain concentration, and storage vessels confirms. While most settlements disposed of low quality raw materials of local origin, a certain amount of tools were also made of better raw materials, independent of distance to their source. Consequently, the proposed political borders between territories did not affect the grinding processes and quality of the flour in each settlement in the same way. Their populations worked under different technical conditions and consumed flour of different quality, depending on the available grinding equipment.

These qualitative differences among the forces of production acquire a different dimension against the light of the five categories of grave goods identified in the funerary record and can be interpreted in terms of three separate social classes (Lull \& Estévez 1986; Lull et al. 2011). According to the funerary information, about $10 \%$ of the population defined their dominant position in the central settlements through access to specific weapons, such as halberds and, after c. $1800 \mathrm{cal}$. BCE, long swords, as well as through access to gold and silver ornaments. About half of the population had access to more common metal weapons and tools (axes and daggers) and would have represented members with full rights. Finally, about $40 \%$ had practically no access to metals and particularly not to weapons, at least in the funerary domain. This group of poor tombs seems to manifest the existence of an exploited class (servants without rights), which expectedly accomplished heavy work processes such as cereal grinding, in large workshops. Obviously, the percentages of members belonging to each of these three social classes varied form settlement to settlement.

If this social model based on the study of over 1600 El Argar burials is compared with the raw materials used as grinding tools in each settlement, we notice that settlements with less appropriate local resources will always dispose of at least $40 \%$ of high or, at least, middle quality materials, which in many cases needed to be obtained from the territories controlled by other hill-top settlements (Figure 8). The flour ground with these rocks was less contaminated by mineral particles and grinding required less physical effort. Only Los Cipreses has $20 \%$ of high quality rocks, yet this is a small lowland site, probably dependent upon Lorca. In most settlements high and middle quality rocks were used for $60 \%$ of the tools, a proportion that is coincident with the members belonging to the upper half of the social ladder. On the other hand, even territories with access to high quality rocks will nevertheless also select a certain amount of local materials of inferior quality (e.g., Barranco de la Viuda, Gatas). Only in the hill-top settlement of Cabezo Negro are less than $20 \%$ of the tools made of low quality rocks. Considering the long use life of grinding slabs, often extending over several decades, this sloppy and unsystematic selection of raw materials is difficult to explain in a society relying heavily on ground cereals for its subsistence. Instead, 
such an unequal access to resources makes sense in a context of social exploitation and sharp division of labour, where the procurement of raw materials, the use of the grinding tools, and the consumption of the produced flour is not carried out by the same members of society.

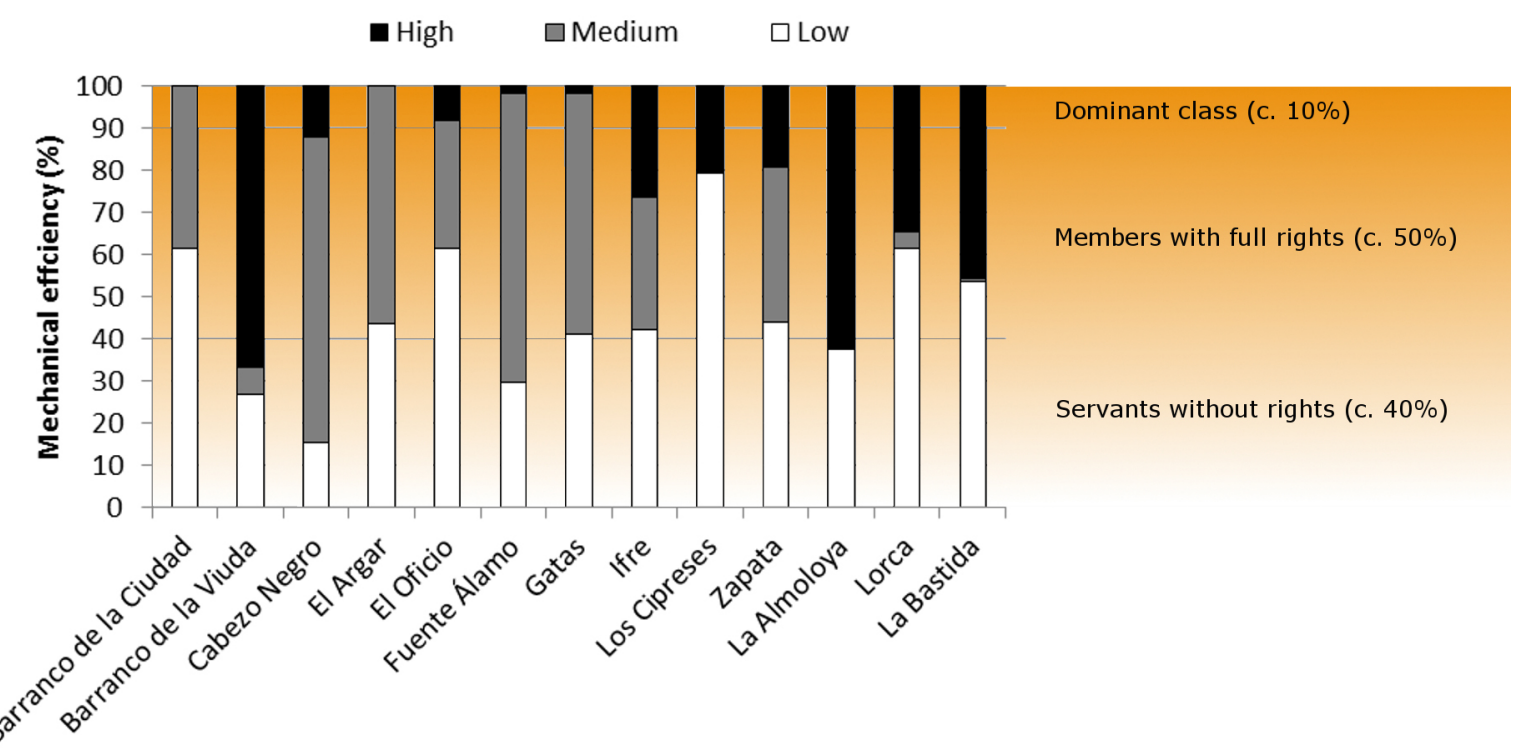

Figure 8. Mechanical efficiency of the grinding slabs inside El Argar settlements projected against the social organisation as seen in the funerary record.

In sum, the social differences represented in the funerary record seem to correlate with an unequal processing and consumption of the main Argaric staple food. Very different working conditions existed not only between but also within the hilltop settlements affecting the working times and the quality of the subsistence base.

\section{Discussion and conclusions}

The first lesson of this study reveals the flawed nature of relying on typological approaches in order to characterise the technical conditions of production processes. The simple classification of macro-lithic tools into grinding slabs, rubbers, polishers, etc. misses a whole artefact category - grain processing handstones - and would not lead to an understanding of the technological changes developed during El Argar together with the new subsistence strategy. A careful recording of the morphological and metrical variables of the working artefacts and their working surfaces, combined with use-wear, and experimental analysis are needed if we want to reach a meaningful definition of the technological conditions ruling a given economy.

The second aspect we hope to have shown is the importance of material and mechanical analyses of the means of production in order to address the social dimension of prehistoric technology. With the beginning of the Argaric period a new type of technology allowed increasing economic productivity, particularly in the case of grinding barley. Behind this apparent improvement brought about by the introduction of convex grinding slabs in combination with wooden rubbers, however, important inequalities existed among producers and consumers of flour due to the differences in the mechanical capacity of the grinding equipment available in the settlements. The establishment of sharp territorial borders between major political and economic centres seems to have limited the circulation of bulk production even between neighbouring regions. The Argaric socio-economic system prioritized political control over the technical conditions of work as producers no longer controlled natural resource management, nor the efficiency of grinding equipment. Evident differences in 
grinding capacity between communities and inside each settlement must have had serious consequences in the working times and in the quality of subsistence. The mechanical test of the different rocks used as grinding tools imply that some communities and some classes would have had to work longer for getting their food and that this food was of inferior quality. In this sense, El Argar is a clear example of reduction or even limitation of the available technical solutions due to territorial control and limited circulation of goods.

\section{Acknowledgments}

We would like to thank M. Rosas Casals (Heat Engines Department, Universitat Politècnica de Catalunya - Barcelona Tech) for her unconditional assistance in the processing of the data coming from the mechanical tests. This research has been supported by the Ministry of Economy and Competitiveness (HAR2014-53860-P).

\section{References}

Adams, J. 1999, Refocusing the role of food-grinding tools as correlates for subsistence strategies in the U.S. Southwest. American Antiquity, 64(3): 475-498. doi:10.2307/2694147

Anderson, O. 1976, Times Series Analysis and Forecasting: The Box-Jenkins Approach. London Butterworths, London, 182 p.

Arnanz, A. M. 1991, Materiales carpológicos del yacimiento de Peñalosa (Baños de la Encina, Jaén). Trabajos de Prehistoria, 48: 408-420. (in Spanish) (“Carpological material of the site Peñalosa (Baños de la Encina, Jaén)”). doi:10.3989/tp.1991.v48.i0.538

Ayala, M.M. 1991, El Poblamiento en Lorca. Estado de la Cuestión. Ayuntamiento de Lorca, Real Academia Alfonso X el Sabio, Caja de Ahorros del Mediterráneo, Compobell, Murcia, 531 p. (in Spanish) ("Settlement pattern in Lorca. State of the Art")

Bartlett, K. 1933, Pueblo Milling Stones of the Flagstaff Region and their Relation to Others in the Southwest: A Study in a Progressive Efficiency, Museum of Northern Arizona Bulletin Vol. 3. Northern Arizona Society of Science and Art, Flagstaff, 32 p.

Buikstra, J., Castro, P., Chapman, R., González Marcén, P., Hoshower, L., Lull, V., Micó, R., Risch, R., Sanahuja, M.E., \& Stos-Gale, S. 1990, La necrópolis de Gatas. Anuario Arqueológico de Andalucía, 2: 261-276. (in Spanish) (“The necropolis of Gatas”)

Buikstra, J. Hoshower, L. \& Rihuete, C. 1999, Los enterramientos humanos en los sondeos de Gatas. In: Proyecto Gatas 2. La dinámica arqueoecológica de la ocupación prehistórica (Castro, P., Chapman, R., Gili, S., Lull, V., Micó, R., Rihuete, C., Risch, R. \& Sanahuja, M.E., Eds.), Arqueología Monografías, Sevilla: p. 388-394. (in Spanish) ("Human burials in the survey trenches of Gatas")

Buxó, R. 1997, Arqueología de las Plantas. Crítica, Barcelona, 367 p. (in Spanish) (“Archaeology of plants”)

Carrión, J. S., Fuentes, N., González-Sampériz, P., Sánchez Quirante, L., Finlayson, C., Fernández, S., \& Andrade, A. 2007, Holocene environmental change in a montane región of southern Europe with a long history of human settlement. Quaternary Sciende Reviews, 26: 1455-1475. doi:10.1016/j.quascirev.2007.03.013 
Carrión, J. S., Munuera, M., Dupré, M., \& Andrade, A. 2001, Abrupt vegetation changes in the Segura mountains of southern Spain throughout the Holocene. Journal Ecology, 89: 783-797. doi:10.1046/j.0022-0477.2001.00601.x

Carrión, J. S., Sánchez-Gómez, P., Mota, J. F., Yll, R., \& Chaín, C. 2003, Holocene vegetation dynamics, fire and grazing in the Sierra de Gádor, southern Spain. The Holocene, 13(6): 839-849. doi:10.1191/0959683603hl662rp

Castro, P., Colomer, E., Escoriza, T., Fernández Miranda, M., Fernandes-Posse, M. D., García, A., Gili, S., González, P., López Castro, J. L., Lull, V., Martín, C., Menasanch, M., Micó, R., Montón, S., Olmo, L., Rihuete, C., Risch, R., Ruiz Parra, M., Sanahuja, M.E., \& Tenas, M. 1995, Territoires économiques et sociaux dans le bassin de Vera (Almería, Espagne) depuis c. 4000 cal BC jusqu’à nos jours. In: L'Homme et la Dégradation de l'Environment. XVè Rencontres Internationales d'Archéologie et d'Histoire d'Antibes, 20-22 October 1994 Juan-les-Pins (van der Leeuw, S., Ed.), Éditions Association pour la Promotion et la Diffusion des Connaissances Archéologiques (APDCA), Antibes: p. 299-314. (in French) ("Economic and social territories in the Vera basin (Almería, Spain) from ca. 4000 cal. BC until the present”)

Castro, P., Chapman, R., Gili, S., Lull, V., Micó, R., Rihuete, C., Risch, R., \& Sanahuja, M. E., (Eds.), 1998, Aguas Project. Paleoclimatic Reconstruction and the Dynamics of Human Settlement and Land-use in the Area of the Middle Aguas (Almería), in the South-East of the Iberian Peninsula, Research results. Publications of the European Commission: Science, Research and Development, Luxembourg, 98 p.

Castro, P., Chapman, R., Gili, S., Lull, V., Micó, R., Rihuete, C., Risch, R., \& Sanahuja, M. E., (Eds.), 1999, Proyecto Gatas 2. La Dinámica Arqueoecológica de la Ocupación Prehistórica, Monografías Arqueológicas. Consejería de Cultura de la Junta de Andalucía, Sevilla, 426 p. (in Spanish) (“Gatas Project 2. Archaeo-ecological dynamics of the prehistoric occupation”)

Clapham, A. J., Jones, M. K., Reed, J., \& Tenas, M. 1994, Análisis carpológico del proyecto Gatas. In: Proyecto Gatas: Sociedad y Economía en el Sudeste de España c. 2500-900 cal ANE (Castro, P., Colomer, E., Courty, M. A., Federoff, N., Gili, S., GonzálezMarcén, P., Jones, M. K., Lull, V., Mcglade, J., Micó, R., Montón, S., Rihuete, C., Risch, R., Ruiz Parra, M., Sanahuja, M.E., \& Tenas, M., Eds.), Research Report 1994. Presented at the Junta de Andalucia, Sevilla: p. 633-657. (in Spanish) (“Carpological analysis of the Gatas Project”)

Clapham, A. J., Jones, M., Reed, J., \& Tenas, M. 1999, Análisis carpológico del proyecto Gatas. In: Proyecto Gatas 2. La Dinámica Arqueoecológica de la Ocupación Prehistórica (Castro, P., Chapman, R., Gili, S., Lull, V., Micó, R., Rihuete, C., Risch, R. \& Sanahuja, M.E., Eds.), Monografías Arqueológicas, Consejería de Cultura de la Junta de Andalucía, Sevilla: p. 311-319. (in Spanish) ("Carpological analysis of the Gatas Project”)

Delgado-Raack, S. 2008, Prácticas Económicas y Gestión Social de Recursos (Macro)líticos en la Prehistoria Reciente (III-I milenios AC) del Mediterráneo Occidental. Unpublished PhD dissertation, Universitat Autònoma de Barcelona, Bellaterra, 739 p. (in Spanish) ("Economic Practices and Social Management of (Macro)lithic Resources During Recent Prehistory (III-I millennia BC) in the Western Mediterranean”). URL: http://hdl.handle.net/10803/5528 
Delgado-Raack, S. 2013, Tecnotipología y Distribución Espacial del Material Macrolítico del Cerro de la Virgen de Orce (Granada). Campañas 1963-1970. Una Aproximación Paleoeconómica, British Archaeological Reports, International Series Vol. 2518. Archaeopress, Oxford, 256 p. (in Spanish) ("Tecno-typology and Spatial Distribution of the Macrolithic Material of Cerro de la Virgen de Orce (Granada). Campaigns 19631970. A Paleo-Economic Approach”).

Delgado-Raack, S., Gómez-Gras, D., \& Risch, R. 2009, The mechanical properties of macrolithic artifacts: a methodological background for functional analysis. Journal Archaeological Science, 36(9): 1823-1831. doi:10.1016/j.jas.2009.03.033

Delgado-Raack, S., \& Risch, R. 2009, Towards a systematic analysis of grain processing technologies. In: Recent Functional Studies on Non Flint Stone Tools: Methodological Improvements and Archaeological Inferences, 23-25 May 2008 Lisboa (Aráujo Igreja, M., \& Clemente Conte, I., Eds.), Padrao des Descobrimentos, Lisbon: p. 1-20.

Delgado-Raack, S., \& Risch, R. 2015, Social change and subsistence production in the Iberian peninsula during the 3rd and 2nd millennium BCE. In: Setting the Bronze Age Table: Production, Subsistence, Diet and their Implications for European Landscapes, Proceedings of the International Workshop Socio Environmental Dynamics over the Last 12,000 Years: The Creation of Landscapes III, 15-18 April 2013 Kiel (Kneisel, J., Kirleis, W., del Corso, M., Scholz, H., Taylor, N., \& Tiedtke, V., Eds.), Universitätsforschungen zur Prähistorischen Archäologie Kiel, Habelt, Kiel: p. 21-46.

Gronenborn, D. 1994, Ethnoarchäologische Untersuchungen zur rezenten Herstellung und Nutzung von Mahlsteinen in Nordost-Nigeria. Experimentelle Archäologie in Deutschland, 8: 45-55. (in German) ("Ethno-archaeological studies on recent production and use of grinding stones in North-eastern Nigeria”)

Hayden, B. 1987, Traditional metate manufacturing in Guatemala using chipped stone tools. In: Lithic Studies Among the Contemporary Highland Maya (Hayden, B., Ed.), University of Arizona Press, Arizona: p. 8-119.

Holter, U., \& Schön, W. 1988, Zum Gebrauch von Reib- und Mahlsteinen in der Ostsahara. Archäologische Informationnen, 11: 156-160. (in German) ("Use of hand and grinding stones of the Eastern Sahara”)

Horsfall, G. A. 1987, Design theory and grinding stones. In: Lithic Studies Among the Contemporary Highland Maya (Hayden, B., Ed.), University of Arizona Press, Tucson: p 332-377.

Hürlimann, F. 1965, Neolithische Reibmühlen von einer Ufersiedlung am Greifensee. Jahrbuch der Schweizerischen Gesellschaft für Urgeschichte, 52: 72-86. (in German) ("Neolithic grinding slabs from a lakeside settlement in the Greifensee")

Kunter, M. 1990, Menschliche Skelettreste aus Siedlungen der El Argar-Kultur, Madrider Beiträge, 18. Philipp von Zabern, Mainz am Rhein, 170 p. (in German) ("Human bone remains from El Argar settlements”)

Lull, V., \& Estévez, J, 1986, Propuesta metodológica para el estudio de las necrópolis argáricas. In: Actas del Congreso “Homenaje a Luis Siret (1934-1984)”, June 1984 Cuevas del Almanzora (Arteaga, O., Ed.), Junta de Andalucía, Madrid: p. 441-452. (in Spanish) ("Proposal of a methodology for the study of the argarican necrópolis") 
Lull, V., Micó, R., Rihuete, C., \& Risch, R. 2010, Metal and social relations of production in the 3rd and 2nd millennia BCE in the Southeast of the Iberian Peninsula. Trabajos de Prehistoria, 67(2): 323-347. doi:10.3989/tp.2010.10042

Lull, V., Micó, R., Rihuete, C., \& Risch, R. 2011, El Argar and the beginning of class society in the Western Mediterranean. In: Sozialarchäologische Perspektiven: Gesellschaftlicher Wandel 5000-1500 v. Chr. Zwischen Atlantik und Kaukasus, 15-18 October 2007 Kiel (Hansen, S., \& Müller, J.,Eds.), Arch. Eurasien, 24, Darmstadt: p. 381-414.

Martínez Rodríguez, A., Ponce García, J., \& Ayala Juan, M.M. 1999, Excavaciones de urgencia del poblado argárico de Los Cipreses, Lorca. Años 1992-93. Memorias de Arqueología 1993(8): 156-182. (in Spanish) ("The rescue excavations of the Argaric site of Los Cipreses, Lorca. Years 1992-93”)

Martínez Rogríguez, A., Precioso Arévalo, M.L., \& Ponce García, J. 2003, La musealización de un yacimiento prehistórico: El parque arqueológico de Los Cipreses (Lorca, Murcia). Revista Arqueomurcia, 1: 1-41. (in Spanish) ("The musealization of a prehistoric site: The archaeologic parc of Los Cipreses (Lorca, Murcia)”).

URL: http://www.arqueomurcia.com/revista/n1/htm/cipreses.htm

Martínez Sánchez, C. 2000, El poblado argárico de la Loma del Tío Ginés. Memorias de Arqueología, 1994(10): 162-205. (in Spanish) (“The Argaric site of Loma del Tío Ginés”)

Menasanch, M., Risch, R., \& Soldevilla, J. A. 2002, Las tecnologías del procesado de cereal en el SE de la Península Ibérica durante el III y II milenio ANE. In: Moudre et Broyer. L'identification fonctionelle de mouture dans la Préhistoire et l'Antiquité, Vol. 1. Méthodes (Procopiou, H., \& Treuil, R., Eds.). Comité des Travaux Historiques et Scientifiques (CTHS) \& Climond Ferrand, Paris: p. 81-110.

Molina, F. 1983, Prehistoria de Granada. Don Quijote, Granada, 131 p. (in Spanish) ("Prehistory of Granada”)

Panyella, A., \& Sabater, J. 1959, El pulimento de la piedra en un pueblo bantu, los fang ntumu de la Guinea Española y su valoración cultural. In: V Congreso Nacional de Arqueología, Zaragoza 1957, Publicaciones del Seminario, Zaragoza: p. 79-86. (in Spanish) ("Stone polishing in a Bantu village, the Fang Ntumu of the Spanish Guinea and their cultural evaluation")

Peña-Chocarro, L. 2000, El estudio de las semillas de Peñalosa. In: Proyecto Peñalosa: Análisis Histórico de las Comunidades de la Edad del Bronce del Piedemonte Meridional de Sierra Morena y Depresión Linares-Bailén (Contreras, F., Ed.), Arqueología Monografías, 10, Dirección General de Bienes Culturales, Sevilla: p. 237256. (in Spanish) ("Peñalosa Project: Historical analysis of the communities of the Bronze Age at the southern foot of Sierra Morena and Linares-Bailén basin”)

Peña-Chocarro, L., \& Zapata, L. 2003, Crop-processing of hulled wheats. In: Le Traitement des Récoltes: un Regard sur la Diversité, du Néolithique au Présent. Actes des XXIIIe Rencontres Internationales d'Archéologie et d'Histoire d'Antibes, 17-19 Octobre 2002 Antibes (Anderson P. C., Cummings L. S., Schippers T. S., \& Simonel B., Eds.), APDCA, Antibes: p. 99-113. 
Peña-Chocarro, L., Zapata, L., González Urquijo, J. E., \& Ibáñez Estévez, J. J. 2000, Agricultura, alimentación y uso del combustible: aplicación de modelos etnográficos en arqueobotánica. III Reunió sobre Economia en el Món Iberic SAGVNTVM-PLAV, Extra-3: 403-420. (in Spanish) (“Agriculture, diet and use of fuel: application of ethnographic models in archaeo-botany”).

URL: http://attic.uv.es/index.php/saguntumextra/article/view/2855

Risch, R. 1995, Recursos Naturales y Sistemas de Producción en el Sudeste de la Península Ibérica Entre 3000 y 1000 ANE. Unpublished PhD dissertation, Universitat Autònoma de Barcelona, Bellaterra, 900 p. (in Spanish) ("Natural resource and production systems in the South-Eastern Iberian Peninsula between 3000 and 1000 BC”).

URL: http://hdl.handle.net/10803/5524

Risch, R. 2002, Recursos Naturales, Medios de Producción y Explotación Social. Un Análisis Económico de la Industria Lítica de Fuente Álamo (Almería), 2250-1400 Antes de Nuestra Era, Iberia Archaeologica, 3. Philipp von Zabern, Mainz am Rhein, 340 p. (in Spanish) ("Natural Resources, Production Means and Social Exploitation. An Economic Analysis of the Stone Industry of Fuente Álamo (Almería), 2250-1400 BC”).

Risch, R. 2008, Grain processing technologies and economic organisation: a case study from the south-east of the Iberian Peninsula during the Copper Age. The Arkeotek Journal, 2(2): 1-20.

Robledo, B., \& Trancho, G. J. 2003, Análisis antropológico y condiciones de vida de la población argárica de Cerro del Alcázar, Serie Informes Arqueológicos. Universidad Complutense de Madrid, Madrid, 29 p. (in Spanish) (“Anthropological analysis and living conditions of the Argaric population of Cerro del Alcázar”)

URL: http://www.ucm.es/info/antropo/trancho/separata/alcazar.pdf

Ruiz, M., Risch, R., González-Marcén, P., Castro, P., \& Lull, V. 1992, Environmental exploitation and social structure in prehistoric southeast Spain. Journal Mediterranean Archaeology, 5(1): 3-38. doi:10.1558/jmea.v5i1.3

Schubart, H., Pingel, V., \& Arteaga, O., (Eds.), 2001, Fuente Álamo, Teil 1: Grabungen von 1977 bis 1991 in einer bronzezeitlichen Höhensiedlung Andalusiens, Madrider Beiträge, 25. Philipp von Zabern, Mainz am Rhein, 461 p. (in German) ("Fuente Alamo, Part 1: Excavations of 1977 to 1991 in a Bronze Age hill top settlement in Andalusia”)

Schuhmacher, T. X. 2003, Die Siedlungskeramik der Grabungen 1985-1991. Untersuchungen zur Chronologie und zum Siedlungsschema der El Argar-Kultur. In: Fuente Álamo (Schuhmacher, T. X., \& Schubart, H., Eds.), Iberia Archaeologica, 4, Philipp von Zabern, Mainz am Rhein: p. 15-295. (in German) ("The settlement pottery from the campaigns 1985-1991. Investigation about the chronology and the settlement pattern of the El Argar culture”)

Siret, L., \& Siret, H. 1890, Las Primeras Edades del Metal en el Sudeste de España. Barcelona, 534 p. (in Spanish) ("The first Metal Ages in South-Eastern Spain”)

Stika, H.-P. 1988, Botanische Untersuchungen in der bronzezeitlichen Höhensiedlung Fuente Álamo. Madrider Mitteilungen, 29: 21-76. (in German) ("Botanical studies on the Bronze Age hill top settlement of Fuente Álamo”) 
Stika, H.-P. 2001, Fuente Álamo - Botanische Ergebnisse der Grabungskampagne 1988 in der bronzezeitlichen Höhensiedlung (Prov. Almería, Südostspanien). In: Fuente Álamo, Teil 1: Grabungen von 1977 bis 1991 in einer bronzezeitlichen Höhensiedlung Andalusiens (Schubart, H., Pingel, V., \& Arteaga, O., Eds.), Madrider Beiträge, 25, Philipp von Zabern, Mainz am Rhein: p. 263-336. (in German) ("Fuente Alamo Botanical results of the 1988 excavation campaign in the Bronze Age hill top settlement (Prov. Almería, South-eastern Spain)”)

Wright, M. K. 1993, Simulated use of experimental maize grinding tools from southwestern Colorado. KIVA, 58: 345-355. URL: http://www.jstor.org/stable/30247404

Zimmermann, A. 1988, Steine. In: Der bandkeramische Fundplatz Langweiler 8, Gemeinde Aldenhoven, Kr. Düren (Böelicke, U., von Brandt, D., Lüning, J., Stehli, P., \& Zimmermann, A., Eds.), Beiträge zur neolithischen Besiedlung der Aldenhovener Platte III, Rheinische Ausgrabungen, 28, Rheinland Verlag, Köln: p. 569-787. (in German) ("Stones") 